\title{
San Carlos City, Negros Occidental: Prospects and Perspectives as Meetings, Incentives, Conventions, and Exhibitions Destination
}

\author{
Cybill Ann A. Ramirez \\ Colegio de Santa Rita, San Carlos City, Negros Occidental, Philippines
}

\section{Article history: \\ Revised: 29 May 2021 \\ Keywords: \\ Hospitality \\ Tourism \\ MICE destination \\ Descriptive \\ San Carlos City}

Submitted: 28 March 2021

Accepted: 15 June 2021

\begin{abstract}
Meetings, incentives, conventions, and exhibitions (MICE) tourism is a specialized area of the tourist industry growing in importance due to the growth of business tourism worldwide. In San Carlos City, the MICE industry is not yet fully developed; assessing the city's potential as a MICE destination is still essential to ascertain if the city has adhered to all the necessary qualifications and has sufficient facilities and services. As a result, using the Five A's of Tourism, the study assessed the potential of San Carlos City, Negros Occidental as a MICE destination and investigated stakeholders' perceived demands, difficulties, and opportunities. Using the quota sampling method, data were gathered from the respondents comprising tourism key players and tourists through a researchermade checklist questionnaire. Descriptive analysis through frequency count and distribution percentage was used to analyze the data. Based on the findings,
\end{abstract} the city shows potential as a MICE-destination as determined using the Five A's of tourism. Generally, the study's findings may provide a basis for a proposed three-year MICE Tourism Development Plan of San Carlos City, Negros Occidental.

\subsection{Introduction}

Meetings, Incentives, Conventions, and Exhibitions (MICE) is one of the most fast expanding tourism industry sectors (Jones \& Li, 2015). It was given the abbreviation MICE, where M stands for meetings, which includes all forms of professional meetings; I is for incentives, which refers to the planning of incentive or corporate travel, $\mathrm{C}$ stands for Conference or Convention, which refers to the organization of various types of meetings such as conferences and other arrangements, and $\mathrm{E}$ stands for Exhibitions or Events, which includes the organization of national and international exhibitions on various exhibition grounds (Jamgade, 2018).

MICE tourism has also become one of ASEAN's most important industrial markets. Several Southeast Asian major cities collaborate with other countries to increase MICE tourism (Ghaffara, et al., 2018). Thailand, for example, is one such country. MICE has also become one of the essential tourism sectors in the country, owing to both national and global benefits (Kerdpitak, 2019). MICE events can also promote a country like South Korea on an international scale as the country is keen on organizing meetings and other activities tailored for international travelers (Han et al., 2019).

The convention, meetings, and entertainment industries also continue to thrive and develop in a country like the Philippines. Manila, Cebu, and Davao have all become popular MICE destinations in the Philippines. These destinations provide the best tourism products and services, as well as countless business prospects, as well as rising local economies that have encouraged investors to build hotels and meeting facilities.

In San Carlos City, the MICE industry is not yet fully developed. Although San Carlos City can host modest local events, the city's potential as a Meetings, Incentives, Conventions, and Exhibitions destination has yet to be determined (MICE) destination is still necessary to determine if the city has adequate facilities and services to operate as Meetings, Incentives, Conventions, and Exhibitions (MICE) destination, which is open to all tourists and associations from anywhere in the Philippines.

Several studies and literature focused on MICE tourism such as MICE tourism development (Hamid et. al., 2012), internationalization of the MICE industry (Smagina, 2017), and studies relating to MICE tourism in ASEAN countries (ASEAN, 2018) like Thailand (Kerdpitak, 2019), Indonesia (Ghaffara et al., 2018), Korea (Han et al., 2019) and the Philippines such as Bacolod City, Philippines as Meetings, Incentives, Conventions, and Events Destination ( Haguisan III \& Mendoza, 2015 ), and the assessment of the MICE industry in the Philippines (Francisco, 2017). There were also studies about MICE tourism in Ethiopia (Degarege \& Lovelock, 2020). However, there was limited literature on the potential of cities as a MICE destination in terms of the five A's of tourism, specifically here in San Carlos City, Negros Occidental. This dearth in the literature is what the study would like to fill. 
Hence, the study assessed San Carlos City's potential as a Meetings, Incentives, Conventions, and Events destination using the five A's of tourism. Furthermore, the study also investigated stakeholders' perceived demands regarding business and trade, educational and scientific activities, sports and entertainment, and arts and culture. Lastly, it sought to determine the challenges and opportunities of San Carlos City as a MICE destination. The study results were used to formulate a three-year MICE Development Plan in San Carlos City, Negros Occidental.

\subsection{Framework of the Study}

The study is anchored on the improved Tourism Development Theory. This tourist development model determines the five key parts of tourist development. Transportation, resorts, visitor behavior, attitudes, and appealing tourism regions are among them. The five elements are self-evolving and provide a broad picture of the tourism industry's progress (Butler, 1997). Five phases occur in the tourism development model $(0,1,2,3$, and 4$)$, representing Discovery Stage, Growth and Development Stage, Success Stage, Problem - Stagnation Stage, and Decline or Decline Rejuvenation.

The benefit of this approach reveals how tourism development is revealed in detail not only by the physical changes that have remained but also by the mental factors that influence visitor behavior. When services are given to fulfill the demands of tourists in the area, changes occur. The principal change attracts travelers' attention. These efforts include developing the region's image, which is dependent on tourism marketing and the ability to attract tourists for the first time (Lewis \& Delisle, 2004). If the promotion is successful, tourists will become interested in the area, and the area will undergo rapid changes that will help the economy grow.

Moreover, Martín et al. (2016) stated that the MICE destination constitutes a combination of amenities, ancillary services, accessibility, attractions, and activities. In the study of Bulatović and Rajović (2015), it was mentioned that the attributes that enabled Macau to achieve success as a MICE-destination and found that accessibilities, amenities, and attractions were essential among other attributes. For MICE tourism to succeed, event organizers, participants, host destinations, and associations must consider destination qualities. Because of the increased global competition for MICE tourism, location organizers must accurately identify the essential model for facilitating successful events and begin marketing initiatives based on the wants and desires of attendees.

Furthermore, increasing income from tourism should rest not only on blindly raising the annual number of tourists but also on making the country more attractive and engaging to new markets and strengthening strategies for high-income types of tourism. MICE tourism, unlike other segments of tourism, boasts much higher spending (Katsitadze \& Natsvlishvili, 2017). Its participants also demand products and services of much higher quality - while also consuming other tourist products (MICE tourism products + vacation/MICE tourism products + sightseeing, etcetera). This fact is easily proven by simple observation of tourists' rate at the international market $(25 \%)$ and their spending (60\%). Therefore, MICE tourism also provides effective mechanisms to support tourism development from socio-economic and ecological views.

\subsection{Methods}

Descriptive research was utilized in this study to describe the potential of San Carlos City as a MICE destination in terms of the five A's of tourism-attractions, accessibility, accommodation, amenities, and activities. Also, the study described the stakeholders' perceived demands in terms of business and trade, educational and scientific, sports and entertainment and arts and cultural. Furthermore, it determined the challenges and opportunities of San Carlos city as a MICE-destination.

The respondents of the research were the key players in tourism and tourists in San Carlos City. Using quota sampling, respondents comprised 55 association officers, 26 local events planning employees, 12 local tour and travel operators, 11 city tourism officers, and 300 tourists.

The data were collected using a researcher-made checklist questionnaire that went through a test of reliability and test of validity. The data were treated and analyzed using frequency count and percentage distribution. 


\subsection{Results and Discussion}

\section{The MICE potential of San Carlos City, Negros Occidental}

Attraction. Table 1 shows that all respondents believed that San Carlos City, Negros Occidental has attraction potential as a MICE-destination and that the city has excellent destination planning and can offer a variety of tourism attractions for tourists' delight. The findings further show that the city showcases diverse cultural and eco-friendly man-made and natural attractions. According to Hazarhun et al. (2019), the countries' historical and cultural resources are among the most crucial tourist attractions; culture is one of the most important sources of motivation that motivates visitors to travel and influences their destination choice. As a result, cultural resources enable destinations to compete with other destinations.

Further, Avraham (2016) emphasized that a destination's appeal is frequently deciding in tourism activities. Unique attractions are one crucial element in the formation of the destination, and it integrates as the symbol of the city (Çevik \& Sariipek, 2019). Furthermore, in Kerdpitak's (2019) study, it was mentioned that there are two types of attractions that are typically considered by travellers. The first being a location's natural attractions like flora and fauna, its overall climate, and the environment of the destination. Secondly, artificial attractions include museums, water sports, theme parks, and other man-made tourist areas that factor into the decision-making process for tourists. In addition to these attractions, a destination's image, safety, security, hotel reputation, and place of the actual MICE event are necessities for MICE travelers.

When it comes to natural beauties, historical and cultural features that make the convention destination enticing, it is easier for conference organizers to exhibit such areas. As a result, physical, historical, cultural, and recreational elements, regarded as the essential sources of destination competition in congress tourism, are recognized as the most crucial cause for destination appeal and motivation. These elements influence tourists' length of stay and spending volume and are a direct cause of travel and attraction for people (Bahar \& Kozak, 2005). These elements provide additional value to a location or MICE event, and tourism effectively does not exist without such attractions (Alananzeh et al., 2018).

Table 1. San Carlos City as potential MICE destination in terms of attraction

\begin{tabular}{llrrr}
\hline \multicolumn{1}{c}{ Attraction } & \multicolumn{2}{c}{ Yes } & \multicolumn{2}{c}{ No } \\
\cline { 2 - 5 } & f & $\%$ & $f$ & $\%$ \\
\hline 1. $\begin{array}{l}\text { The city promotes its ecozone as one of its } \\
\text { main attractions. }\end{array}$ & 402 & 99.5 & 2 & 0.5 \\
$\begin{array}{l}\text { The city showcases man-made attractions in } \\
\text { terms of plaza, landmarks, and picnic parks. }\end{array}$ & 402 & 99.5 & 2 & 0.5 \\
$\begin{array}{l}\text { The city provides tourist attractions with friend- } \\
\text { ly staff that can cater to the needs of the guest. }\end{array}$ & 401 & 99.3 & 3 & 0.7 \\
$\begin{array}{l}\text { The city has diverse cultural and historical } \\
\text { attractions in terms of architecture, tradition, } \\
\text { and customs. }\end{array}$ & 388 & 96.0 & 16 & 4.0 \\
$\begin{array}{l}\text { The city is thriving with natural attractions such } \\
\text { as beaches, falls, mountain peaks, and lake. }\end{array}$ & 319 & 79.0 & 85 & 21.0 \\
\hline
\end{tabular}

Accessibility. As shown in Table 2, the findings indicate that San Carlos City can facilitate the needs of the tourists in terms of transportation and accessible attractions since the majority if not all of the respondents agreed that in terms of accessibility, the city has the potential as a MICE-destination. 
Another critical aspect of MICE tourism is accessibility, which refers to the interaction between tourists and transportation (Kerdpitak, 2019). Kelly and Nankervis (2001) suggested in their study that accessibility indicates the flexibility of traveling from one place to another and should allow attendees to travel efficiently and affordably to and from the conference destination. Effective transportation options should be linked with tourist areas and with the MICE destination. For instance, the center should typically be situated close to a major airport with access to adequate transportation, highways, and hotels.

Table 2. San Carlos City as potential MICE destination in terms of accessibility

\begin{tabular}{llrrr}
\hline \multicolumn{1}{c}{ Accessibility } & \multicolumn{3}{c}{ Yes } & \multicolumn{2}{c}{ No } \\
\cline { 2 - 5 } & $\mathrm{f}$ & $\%$ & $\mathrm{f}$ & $\%$ \\
\hline 1. $\begin{array}{l}\text { The city provides roads that are in good condi- } \\
\text { tion for travelers' convenience going in and out } \\
\text { of the city. }\end{array}$ & 398 & 98.5 & 6 & 1.5 \\
$\begin{array}{l}\text { The travel time to and from San Carlos City } \\
\text { does not take more than 5- 10 hour }\end{array}$ & 395 & 23.5 & 9 & 2.2 \\
$\begin{array}{l}\text { The city sets up organized tourist-friendly } \\
\text { transportation services }\end{array}$ & 392 & 97.0 & 12 & 3.0 \\
$\begin{array}{l}\text { The city provides accessible facilities/services } \\
\text { for disabled tourists(e.g., ramps, easy to open } \\
\text { doors, accommodating staff) }\end{array}$ & 391 & 96.8 & 13 & 3.2 \\
$\begin{array}{l}\text { The city ensures that there are enough vehicles } \\
\text { for Land, Sea, and Air Transport with numerous } \\
\text { available schedules }\end{array}$ & 375 & 92.8 & 29 & 7.2 \\
\hline
\end{tabular}

Sangeetha (2015) also heavily emphasized that to be a hot spot for MICE tourism, a destination needs to be designed, developed, and promoted through a blend of tourism and business. Infrastructural facilities, accessibility, accommodation, venues need to be of international standard and quality. A study by Macmillan Education Ltd and Meidan (2015) confirmed that $40 \%$ of a participant's expenditure went towards accommodation, followed by $39 \%$ on transportation, with the remaining assets spent on other activities such as shopping or recreation. Good accessibility, therefore, affects the success of MICE events for any country and subsequently impacts global competition.

Accommodation. As found in Table 3, the city has potential as a MICE destination in terms of accommodation. The results indicate that San Carlos City can offer accommodation with complete amenities for business travelers to stay during MICE events, and some of its hotels and inns have met the Department of Tourism standards. The findings further exhibit that San Carlos City can accommodate large groups of MICE participants. Hotels and inns within the city can take advantage by housing all related activities (in case of a convention), including accommodation and food and beverage services.

Every meeting, according to Fang (2020), had specific sites for audience housing and dining. The hotel features several outstanding meeting rooms and assembly halls. If the conference hall's carrying capacity is insufficient to accommodate everyone, there is not enough lodging in the region to accommodate all attendees. It makes no sense to keep it there in this manner. While many participants might be ready to travel a short distance to attend, many would be unable to do so owing to a lack of accommodations. According to a study by Sylla et al. (2015), because of their short time, such guests must be provided with comfortable housing, access to a restaurant, and proximity to the location of the assembly or conference. The MICE package service includes accommodation for delegates and guests, a convention center, an exhibition hall, and audio-visual services at highend hotels and resorts. The more resources available, the more MICE destinations will emerge (Giao \& Le, 2020). 
Table 3. San Carlos City as potential MICE destination in terms of accommodation

\begin{tabular}{|c|c|c|c|c|c|}
\hline & \multirow{2}{*}{ Accommodation } & \multicolumn{2}{|c|}{ Yes } & \multicolumn{2}{|c|}{$\underline{\text { No }}$} \\
\hline & & $f$ & $\%$ & $f$ & $\%$ \\
\hline 1. & $\begin{array}{l}\text { The hotels and inns in San Carlos provide } \\
\text { sufficient and high-standard facilities } \\
\text { supporting guests/event participants with } \\
\text { disabilities. }\end{array}$ & 392 & 97.0 & 12 & 3.0 \\
\hline 2. & $\begin{array}{l}\text { The hotels and inns in San Carlos also } \\
\text { provide larger rooms for family/ group } \\
\text { tours with complete amenities and a hot } \\
\text { and cold shower. }\end{array}$ & 390 & 96.5 & 14 & 3.5 \\
\hline 3. & $\begin{array}{l}\text { The hotels/ inns in San Carlos City have } \\
\text { available high-standard function halls. }\end{array}$ & 382 & 94.6 & 22 & 5.4 \\
\hline 4. & $\begin{array}{l}\text { There are good hotels/inns in San Carlos } \\
\text { City that can accommodate big groups of } \\
\text { tourists/event participants. }\end{array}$ & 371 & 91.8 & 33 & 8.2 \\
\hline 5. & $\begin{array}{l}\text { The hotels and inns in San Carlos City } \\
\text { has met all the Department of Tourism } \\
\text { Accommodation Standards }\end{array}$ & 350 & 86.6 & 54 & 13.4 \\
\hline
\end{tabular}

These are the primary criteria that influence the selection of a hotel as a venue for business events and meetings. A study in Australia by Dwyer and Mistilis (2016) showed that international MICE tourists' largest expenditure items within Australia were on accommodation, shopping, and food and drink. Hence, accommodation plays a vital role in the MICE industry, so it is also essential to plan to host MICE events.

Amenities. In Table 4, the city has potential as a MICE destination in terms of amenities. Also, the findings generally indicate that San Carlos City can provide essential amenities to tourists. Amenities refer to the necessary facilities provided by a host destination to meet the needs of the delegates and uphold the quality of MICE events. These facilities usually include health care facilities, freight forwarding, effective communication systems, wellness centers, sports centers, entertainment centers, and qualified employees to serve the MICE participants (Marais et al., 2017).

The destination should also offer these services for leisure time: Swimming pools, massage rooms, saunas, gyms, solariums, and other recreational activities are all advised. The first offering of cultural and social services, such as theatre, movie, or travel organizing to fascinating sites, was made to accommodate business travelers (Ali et al., 2017). In the study of Chiu and Ananzeh (2012), a destination could globally compete in hosting MICE events when it has sufficient attributes like facilities and amenities for conventions and exhibitions available to potential MICE travelers. Therefore, all facilities should be available either within or near the hotel or in the convention center; consequently, this can help improve the tourist experience when they stay in San Carlos City.

Activities. Based on Table 5, the city shows potential as a MICE destination in terms of activities. Local tourism activities are vital to tourists' experiences. The local economy is changing, and increasing investment is directed to tourism activities, ranging from accommodation to entertainment (Ponte et al., 2018).

In the study of Rogerson (2015) and Castro (2018), MICE participants usually attending the hosted events with their family or friends, with a reported $60 \%$ of attendees planning to engage in recreational activities with family and friends in addition to the MICE events. Furthermore, tourism activities provide folks with comfort and leisure options, which makes them happy. Tourism can help to foster harmony by allowing people to get to know one another, gain experience, and make friends (Rhaman, 2016). Furthermore, the leisure activities offered in a MICE location are critical to the event's success (Kerdpitak, 2019). 
Table 4. San Carlos City as potential MICE destination in terms of amenities

\begin{tabular}{|c|c|c|c|c|c|}
\hline & \multirow{2}{*}{ Amenities } & \multicolumn{2}{|c|}{ Yes } & \multicolumn{2}{|c|}{ No } \\
\hline & & $f$ & $\%$ & $f$ & $\%$ \\
\hline 1. & $\begin{array}{l}\text { There are sports/ recreational centers within } \\
\text { the city available for outdoor and indoor } \\
\text { activities. }\end{array}$ & 399 & 98.8 & 5 & 1.2 \\
\hline 2. & $\begin{array}{l}\text { There are good shopping malls/grocery stores } \\
\text { /retail shops/ pasalubong centers around the } \\
\text { city. }\end{array}$ & 396 & 98.0 & 8 & 2.0 \\
\hline 3. & $\begin{array}{l}\text { The city has wellness/spa facilities made } \\
\text { available for the relaxation of the locals and } \\
\text { tourists. }\end{array}$ & 396 & 98.0 & 8 & 2.0 \\
\hline 4. & $\begin{array}{l}\text { The city has enough water and electricity } \\
\text { supply to provide for large conventions and } \\
\text { events }\end{array}$ & 395 & 97.8 & 9 & 2.2 \\
\hline 5. & $\begin{array}{l}\text { The city has numerous restaurants/ food joints } \\
\text { that offer a wide variety of local and foreign } \\
\text { cuisines. }\end{array}$ & 387 & 95.8 & 17 & 4.2 \\
\hline
\end{tabular}

Table 5. San Carlos City as potential MICE destination in terms of activities

\begin{tabular}{|c|c|c|c|c|c|}
\hline & \multirow{2}{*}{ Activities } & \multicolumn{2}{|c|}{ Yes } & \multicolumn{2}{|c|}{ No } \\
\hline & & $f$ & $\%$ & $f$ & $\%$ \\
\hline 1. & $\begin{array}{l}\text { The city offers cultural and other festive events such } \\
\text { as Tourism and Heritage Week, Pintaflores Festival, } \\
\text { Competitions related to the culture and the arts }\end{array}$ & 403 & 99.8 & 1 & 0.2 \\
\hline 2. & $\begin{array}{l}\text { The city offers diverse business and trade activities, } \\
\text { agriculture, tourism, educational and scientific, } \\
\text { sports, and the Arts, PWD. friendly activities }\end{array}$ & 399 & 98.8 & 5 & 1.2 \\
\hline 3. & $\begin{array}{l}\text { The city is often the choice for a venue for different } \\
\text { associations and events. }\end{array}$ & 393 & 97.3 & 11 & 2.7 \\
\hline 4. & $\begin{array}{l}\text { There is a constant provision of activities in the city } \\
\text { that is related to nightlife and entertainment. }\end{array}$ & 380 & 94.1 & 24 & 5.9 \\
\hline 5. & $\begin{array}{l}\text { The tourist spots in the city offer different physical } \\
\text { activities such as snorkeling, biking, and mountain } \\
\text { trekking. }\end{array}$ & 312 & 77.2 & 92 & 22.8 \\
\hline
\end{tabular}

\section{Stakeholders' Perceived Demands of San Carlos City as a MICE Destination}

Business and Trade. Table 6 shows that the highest stakeholders' perceived demands in terms of business is the marketplace. Based on the responses, most respondents answered YES for each facility under business and trade, which means that stakeholders strongly demand that San Carlos City provide the facilities related to business and trade to meet the preferences of the business travelers.

In Beaverstock's (2016) study, business and enterprise Tourism is a vital part of the global economy, comprising a steady and significant flow of people from all over the world for short or lengthy stays. Moreover, Business tourism is an inextricable part of the increase in urban tourism, especially when it comes to constructing purpose-built conference halls as part of economic growth 
and regeneration initiatives (Hermelin, 2012). Swarbrooke and Horner (2012) organize the theme of 'business tourism' into at least fifteen distinct travel categories, including training courses, general business trips, product launches, incentive travel, and corporate hospitality. Nonetheless, the industry is often regarded as encompassing both solo business visits and travel for meetings, incentives, conferences, and exhibits tourism (Rogerson, 2015).

Furthermore, Business Tourism has correlated to a tourism sector with significant growth potential. Low seasonality, regulated environmental impact, increased revenue for lodging and conference venues, strong demand for food and beverage ( coffee breaks, gala dinners, lunches, etcetera ), and increased leisure activities. Some of the primary characteristics that make Business Tourism appealing to locations are its relative resilience to the present economic crisis and its relative resilience to the present economic crisis. The rivalry for MICE travelers, both locally and globally, is fierce due to the enormous potential benefits of expanding as a strong business tourism destination (Celuch, 2014; Dorfler, 2002; Kim, Sun, \& Ap, 2008; Weber \& Ladkin, 2003).An increasing number of countries and localities are developing conference facilities and bidding for events to profit from this tourism area (Campiranon \& Arcodia, 2008; Law, 1993; Monge \& Brandimarte, 2011; Oppermann, 1997). The significant measures for the development of a flourishing Business Tourism in the territory, according to Marques and Santos (2016), are as follows: 1) better structuring and requalification of Business Tourist facilities (venues, hotels, and restaurants), with a focus on improving service quality; 2) better management of tourism activity and resources; participation of various agents; and enhancement of complementary tourism product.

Table 6. Stakeholders' perceived demands in terms of business and trade

\begin{tabular}{lcccc}
\hline \multirow{2}{*}{ Business and Trade } & \multicolumn{3}{c}{ Yes } & \multicolumn{2}{c}{ No } \\
\cline { 2 - 5 } & $\mathrm{f}$ & $\%$ & $\mathrm{f}$ & $\%$ \\
\hline Marketplace & 402 & 99.5 & 2 & 0.5 \\
Hotel Venues & 401 & 99.3 & 3 & 0.7 \\
Fairs & 397 & 98.3 & 7 & 1.7 \\
Cultural Events & 396 & 98.0 & 8 & 2.0 \\
Resort Venues & 391 & 96.8 & 13 & 3.2 \\
Exhibitions & 381 & 94.3 & 23 & 5.7 \\
Private Parties & 339 & 83.9 & 65 & 16.1 \\
Convention centers & 271 & 67.1 & 133 & 32.9 \\
\hline
\end{tabular}

Educational and Scientific Activities. As shown in Table 7, the stakeholders' perceived demands regarding educational and scientific activities, the highest demand are universities. However, more than half of the respondents do not demand that the city have observatories, scientific conferences, and museums because they do not believe they can maintain or establish these facilities. Despite the responses provided by the stakeholders, these will still be included as references in the improvement of the tourism development plan of the city in the future.

Edu-tourism refers to any program in which participants travel to a location either individually or in a group with the primary motive in having a learning experience (Bodger, 1998). Already in 2004, the United Nations World Tourism Organization (UNWTO) recognized the need to grow the educational tourism business by utilizing "the benefits of a diverse range of education and available methodologies" (UNWTO, 2014).

In this regard, it is vital to assess and adequately utilize educational tourism's backbone aspects, which include teachers, students, and educational programs. As a result, educational tourism can be viewed as both a practical training technology and a method of organizing an educational process. The establishment of scientific and educational tourism centers allows diverse educational, tourist, and administrative entities to coordinate their adoption of new educational technologies (Shamshina et al., 2017). 
Table 7. Stakeholders' perceived demands in terms of educational and scientific activities

\begin{tabular}{lcccc}
\hline \multirow{2}{*}{ Educational and Scientific Activities } & \multicolumn{3}{c}{ Yes } & \multicolumn{2}{c}{ No } \\
\cline { 2 - 5 } & $f$ & $\%$ & $f$ & $\%$ \\
\hline Universities & 402 & 99.5 & 2 & 0.5 \\
Workshops & 401 & 99.3 & 3 & 0.7 \\
Educational Trips & 397 & 98.3 & 7 & 1.7 \\
Galleries & 396 & 98.0 & 8 & 2.0 \\
Laboratories & 391 & 96.8 & 13 & 3.2 \\
Observatories & 381 & 94.3 & 23 & 5.7 \\
Scientific Conferences & 339 & 83.9 & 65 & 16.1 \\
\hline Museums & 271 & 67.1 & 133 & 32.9 \\
\hline
\end{tabular}

In the study of Sou and McCartney (2015), education plays a crucial role in nurturing talents for the MICE industry as there is a continuing need to develop event management professionals who can create, organize, and manage events. Training and service standards are significant challenges for the burgeoning MICE business in the region, which is experiencing rapid growth and rising competitiveness. Tourism education and training should improve managers' capacity to employ various techniques to improve their efficiency and responsiveness (Mistilis \& Dwyer, 2000).

Sports and Entertainment. In Table 8, the findings show that the highest demands in terms of sports and entertainment are sports facilities. Since privately operated sports facilities got the highest demand based on the stakeholders' perspective, it is essential to meet those demands since sports tourism is one of the fastest-growing sectors in tourism and can help improve the economy of the city and offer more diverse services and facilities of San Carlos City as a MICE-destination.

Sport is now identified as the world's most extensive social phenomenon (Kurtzman \& Zauhar, 2003), and tourism its most prominent industry (Goeldner et. al., 2001). Because inhabitants directly feel the improvement of economic benefits and endowments by giving new, additional social and recreational opportunities and the promotion/development of new infrastructure, sports tourism activities have an essential enriching social potential (Fredline, 2005). In sports events in MICE also require special-purpose facilities, including athletic parks, arenas, and stadiums (Alananzeh et al., 2018). In addition, the study of Mokras-Grabowska (2016) mentioned that sports tourism participants typically employ conventional tourist infrastructure (catering facilities, to accommodation, transportation, and supporting facilities), as well as sports and recreation facilities that are open to all tourists, regardless of their purpose to travel.

Table 8. Stakeholders' perceived demands in terms of sports and entertainment

\begin{tabular}{lcccc}
\hline \multirow{2}{*}{ Sports and Entertainment } & \multicolumn{3}{c}{ Yes } & \multicolumn{2}{c}{ No } \\
\cline { 2 - 5 } & $\mathrm{f}$ & $\%$ & $\mathrm{f}$ & $\%$ \\
\hline Sports facilities & 398 & 98.5 & 6 & 1.5 \\
Street Performances & 396 & 98.0 & 8 & 2.0 \\
Tournament & 396 & 98.0 & 8 & 2.0 \\
Concert Shows & 392 & 97.0 & 12 & 3.0 \\
Stadium & 386 & 95.5 & 18 & 4.5 \\
Arenas & 283 & 70.0 & 121 & 30.0 \\
\hline
\end{tabular}


Arts and Culture. As shown in Table 9, the highest stakeholders' perceived demands regarding arts and culture are festivals. The stakeholders strongly demand that the prior arts and cultural activities be offered in San Carlos City to ensure tourist satisfaction. Also, providing culture and arts activities can attract tourists and promote the city's unique heritage and culture; hence, they should improve the tourism development plan.

Cultural heritage sites and activities are seen to have the potential to improve the appeal and competitiveness of a MICE venue (Arnett et al., 2003; Arzeni, 2008). As Morrison and Anderson (2002) pointed out, destination branding is utilized to create a distinct character and personality that sets it apart from competitors. Destinations with natural beauty, distinctive cultures, and MICE facilities are predicted to rise in popularity as a prime location for MICE tourism, with heritage and cultural tourism as important secondary attractions (Kim, 2019). In this case, emphasizing the destination's historical and cultural assets can help it grow into a distinctive niche in the tourism market (Apostolakis et al., 2015).

Table 9. Stakeholders' perceived demands in terms of arts and culture

\begin{tabular}{lcccc}
\hline \multirow{2}{*}{ Arts and Culture } & \multicolumn{3}{c}{ Yes } & \multicolumn{3}{c}{ No } \\
\cline { 2 - 5 } & $\mathrm{f}$ & $\%$ & $\mathrm{f}$ & $\%$ \\
\hline Festivals & 403 & 99.8 & 1 & 0.2 \\
Religious Rites & 402 & 99.5 & 2 & 0.5 \\
Commemorations & 399 & 98.8 & 5 & 1.2 \\
Pilgrimages & 393 & 97.3 & 11 & 2.7 \\
Arts Exhibits & 385 & 95.3 & 19 & 4.7 \\
\hline
\end{tabular}

\section{Challenges of San Carlos City, Negros Occidental as a MICE Destination}

The data in Table 10 showed that the city's number one challenge is to have enough convention centers to cater to at least 1,500 delegates. Furthermore, almost half of the respondents believed that it would also be challenging for the city to manage accommodation contracts because there is insufficient proper infrastructure to facilitate MICE activities.

MICE tourism faces numerous problems. They can be broken down into two categories: training and education-the absence of a world-class conference center, and other infrastructure issues (Singh \& Parkash, 2016). Data on MICE tourism is also scarce, for example, how buyers make their purchase decisions, the lack of reliable data on critical markets or trends in the market, and the benefits and drawbacks of MICE tourism. Customer satisfaction in providing recreational activities, avoiding difficult roads, and having relaxation exercises, seminars at the sites, and scheduling more free time during conferences and meetings and finally, the negative environmental consequences are some of the challenges that a MICE destination may face (Abdelkafy \& Hizah, 2016). In addition, Subash (2015) mentioned in their study that adequate training and skill development infrastructure and hence the availability of trained manpower are also the most common challenges in countries like India, Korea, and Egypt who are also planning to establish as a MICE-destination. Safety and security when arranging MICE events are other challenges that were not covered in the study but were highly stressed by Abdelkafy and Hizah (2016). The needs of special-needs tourists and enhancing services, amenities, venue design, and technological advancement are also additional challenges that are vital to MICE-related events' operation and must be considered and addressed by the LGU to establish the city as a MICE destination successfully.

Singh and Parkash (2016) suggest that for MICE to flourish, a good team of airlines, hotels, transportation firms, cultural organizations, boutiques, and travel agents must work together to target potential MICE clients. As a result, promoting stakeholders' combined efforts in structuring MICE tourism and administration of the area as a tourism destination is critical, especially in addressing San Carlos City's challenges in providing support facilities, accommodation, and proper infrastructures to facilitate MICE activities. 
Table 10. Challenges of San Carlos City as a MICE destination

\begin{tabular}{|c|c|c|c|}
\hline & Challenges & $f$ & $\%$ \\
\hline 1. & The city as a MICE-destination can promote sustainable travel & 238 & 58.9 \\
\hline 2. & $\begin{array}{l}\text { There are well-trained professionals in the field of events and } \\
\text { accommodation }\end{array}$ & 220 & 54.5 \\
\hline 3. & The city is active in its promotional activities & 181 & 44.8 \\
\hline 4. & $\begin{array}{l}\text { The city can manage accommodation contracts because there are } \\
\text { enough accommodation facilities }\end{array}$ & 172 & 42.6 \\
\hline 5. & $\begin{array}{l}\text { The city can provide proper infrastructure to accommodate MICE } \\
\text { activities }\end{array}$ & 127 & 31.4 \\
\hline 6. & The city as a MICE-destination can encourage the influx of tourists & 126 & 31.2 \\
\hline 7. & The city can offer any state-of-the-art support facilities and amenities & 123 & 30.4 \\
\hline 8. & The city can gain support from private sectors & 25 & 6.2 \\
\hline 9. & $\begin{array}{l}\text { The city can become a competitive destination if it becomes a MICE } \\
\text { destination }\end{array}$ & 24 & 5.9 \\
\hline 10. & The city can gain support from the local government & 23 & 5.7 \\
\hline 11. & $\begin{array}{l}\text { The city has enough convention centers that can cater to at least } 1500 \\
\text { delegates }\end{array}$ & 23 & 5.7 \\
\hline 12. & $\begin{array}{l}\text { The city as a MICE-destination can have a significant impact on the } \\
\text { economic development of the city. }\end{array}$ & 21 & 5.2 \\
\hline 13. & Hotels are up-to-date in terms of technology. & 21 & 5.2 \\
\hline 14. & $\begin{array}{l}\text { The city can help generate MICE-related jobs that will benefit the } \\
\text { locals of San Carlos City. }\end{array}$ & 17 & 4.2 \\
\hline 15. & $\begin{array}{l}\text { The city as a MICE-destination encourages the practice and promotion } \\
\text { of Ecotourism among the natural attractions of San Carlos City }\end{array}$ & 13 & 3.2 \\
\hline 16. & $\begin{array}{l}\text { The city can encourage and empower a local entrepreneur to } \\
\text { participate in MICE activities }\end{array}$ & 13 & 3.2 \\
\hline 17. & $\begin{array}{l}\text { The city as a MICE-destination can promote the city's unique culture } \\
\text { and history }\end{array}$ & 11 & 2.7 \\
\hline
\end{tabular}

\section{Opportunities of San Carlos City, Negros Occidental as a MICE destination}

The data in Table 11 further presented that the highest opportunity of San Carlos City as a MICEdestination is to promote the city's unique culture and history. According to Safaeva and Adilova's (2020) research, the MICE sector offers excellent benefits to professional travel agents and service providers. Catering companies that provide contract catering services for event participants and guests are one example of such services. MICE activities can increase investments in local tourism infrastructures and generate revenue for the local economy. Especially in the off-season, MICE events assist small businesses in sharing benefits for professionals like photographers or florists (Kerdpitak, 2019). Furthermore, MICE events promote the country internationally as the country organizes a meeting and other activities tailored for international travelers (Han et al., 2019).

Furthermore, MICE tourism generates significant revenue for the country because delegates spend more time and money than leisure tourists (Wan, 2011). It generates significant earnings for allied companies such as transportation, lodging, entertainment, advertising, and leisure (RatajczakMrozek, 2014). The growth of this sector also creates demand in providing good infrastructures such as hotels, public places, and other attractions (Kapareliotis et al., 2010).

Along with other tourism industries, the MICE industry is growing at a rapid pace. There are numerous opportunities available. Even so, controlling any sector aspect is a challenging endeavor that necessitates a specific set of talents and resources (Dwyer \& Mistilis, 2016). San Carlos City 
can take advantage of these opportunities by coordinating with both private and government organizations, tourism associations, and stakeholders to maximize economic growth and make the city a popular destination for MICE events

Table 11. Opportunities of San Carlos City as a MICE destination

\begin{tabular}{|c|c|c|c|}
\hline \multicolumn{2}{|c|}{ Opportunities } & \multirow{2}{*}{$\frac{f}{393}$} & \multirow{2}{*}{$\begin{array}{c}\% \\
97.3\end{array}$} \\
\hline 1. & $\begin{array}{l}\text { San Carlos City as a MICE-destination can promote the } \\
\text { city's unique culture and history. }\end{array}$ & & \\
\hline 2. & $\begin{array}{l}\text { San Carlos City as a MICE-destination encourages the } \\
\text { practice and promotion of Ecotourism among the natural } \\
\text { attractions of San Carlos City. }\end{array}$ & 391 & 96.8 \\
\hline 3. & $\begin{array}{l}\text { San Carlos City can help generate MICE-related jobs that } \\
\text { will benefit the locals of San Carlos City. }\end{array}$ & 391 & 96.8 \\
\hline 4. & $\begin{array}{l}\text { San Carlos City as a MICE-destination can have an im- } \\
\text { mense impact on the economic development of the city. }\end{array}$ & 387 & 95.8 \\
\hline 5. & $\begin{array}{l}\text { San Carlos City as a MICE-destination can encourage the } \\
\text { influx of tourists }\end{array}$ & 383 & 94.8 \\
\hline 6. & The city can gain support from private sectors. & 383 & 94.8 \\
\hline 7. & $\begin{array}{l}\text { San Carlos City can encourage and empower a local } \\
\text { entrepreneur to participate in MICE activities. }\end{array}$ & 381 & 94.3 \\
\hline 8. & The city can gain support from the local government. & 381 & 94.3 \\
\hline 9. & San Carlos City is active in its promotional activities. & 380 & 94.1 \\
\hline 10. & $\begin{array}{l}\text { San Carlos City as a MICE-destination can promote sus- } \\
\text { tainable travel. }\end{array}$ & 379 & 93.8 \\
\hline 11. & $\begin{array}{l}\text { There are well-trained professionals in the field of events } \\
\text { and accommodation. }\end{array}$ & 281 & 69.6 \\
\hline 12. & $\begin{array}{l}\text { San Carlos City can become a competitive destination if it } \\
\text { becomes a MICE destination. }\end{array}$ & 278 & 68.8 \\
\hline 13. & Hotels are up-to-date in terms of technology. & 277 & 68.6 \\
\hline 14. & $\begin{array}{l}\text { The city can manage accommodation contracts because } \\
\text { there are enough accommodation facilities. }\end{array}$ & 232 & 57.4 \\
\hline 15. & $\begin{array}{l}\text { San Carlos can provide proper infrastructure to accom- } \\
\text { modate MICE activities. }\end{array}$ & 223 & 55.2 \\
\hline 16. & $\begin{array}{l}\text { San Carlos City can offer any state-of-the-art support } \\
\text { facilities and amenities. }\end{array}$ & 184 & 45.5 \\
\hline 17. & $\begin{array}{l}\text { San Carlos has enough convention centers that can cater } \\
\text { to at least } 1500 \text { delegates. }\end{array}$ & 166 & 41.1 \\
\hline
\end{tabular}

\subsection{Conclusion}

The findings implied that San Carlos City, Negros Occidental, has the potential as a MICEdestination when viewed according to the five A's of tourism. This indicates that with the proper implementation of tourism projects, the city can become a MICE destination.

Given the findings of the stakeholders' perceived demands and the challenges and opportunities of the city as a MICE destination, it can be concluded that the development of the facilities and enhancement of tourist services is crucial for San Carlos City, Negros Occidental, to become a MICE-destination. 
Therefore, the LGU and concerned tourism key players in the city may consider exploring the opportunities highlighted in the results and including these in their tourism development plan.

\section{REFERENCES}

Abdelkafy, J., \& Hizah, D. (2016). MICE tourism in Egypt: Opportunities and challenges. Journal of Association of Arab Universities for Tourism and Hospitality, 13(3), 61-73. https://doi.org/10.21608/jaauth.2016.53949

Alananzeh, O. A., Masa'Deh, R., Jawabreh, O., Mahmoud, A. A., \& Hamada, R. (2018). The impact of customer relationship management on tourist satisfaction: The case of Radisson blue resort in Aqaba city. Journal of Environmental Management and Tourism, 9(2), 227. https://doi.org/10.14505//jemt.v9.2(26).02

Ali, F., Hussain, K., \& Ryu, K. (2017). Resort hotel service performance (Reserve) - an instrument to measure tourists' perceived service performance of resort hotels. Journal of Travel \& Tourism Marketing, 34(4), 556569. https://doi.org/10.1080/10548408.2016.1208789

Apostolakis, A., Jaffry, S., Sizeland, F., \& Cox, A. (2015). The role of uniqueness in destination branding: The case of historical Portsmouth harbor. EuroMed Journal of Business, 10(2), 198-213. https://doi.org/10.1108/emjb-102014-0036

Arnett, D. B., Laverie, D. A., \& Meiers, A. (2003). Developing parsimonious retailer equity indexes using partial least squares analysis: A method and applications. Journal of Retailing, 79(3), 161-170. https://doi.org/10.1016/ s0022-4359(03)00036-8

Arzeni, S. (2008). Roles and impact of culture and tourism on attractiveness.https://doi. org/10.1787/9789264040731-4-en

ASEAN. (2018). ASEAN MICE VENUE STANDARDS. ASEAN | ONE VISION, ONE IDENTITY, ONE COMMUNITY. https://asean.org/storage/2012/05/ASEAN-MICE-Venue-Standards-Exhibition-Venue.pdf

Avraham, E. (2016). Destination marketing and image repair during tourism crises: The case of Egypt. Journal of Hospitality and Tourism Management, 28, 41-48. https://doi.org/10.1016/j.jhtm.2016.04.004

Bahar, O., \& Kozak, M. (2005). In the process of globalization: international tourism and competitiveness. Detay Publishing.

Beaverstock, J. V. (2016). International business travel in the global economy. https://doi. org/10.4324/9781315589329

Bodger, D. (1998). Leisure, learning, and travel. Journal of Physical Education, Recreation \& Dance, 69(4), 2831. https://doi.org/10.1080/07303084.1998.10605532

Bulatović, J., \& Rajović, G. (2015). Business competitive of tourist destination: The case northeastern Montenegro. European Journal of Economic Studies, 11(1), 23-38. https://doi.org/10.13187/es.2015.11.23

Butler, R. (1997). Modelling Tourism Development. Tourism, development, and growth: the challenge of sustainability. https://books.google.com.ph/books

Campiranon, K., \& Arcodia, C. (2008). Market segmentation in time of crisis. Journal of Travel \& Tourism Marketing, 23(2-4), 151-161. https://doi.org/10.1300/j073v23n02_12

Castro, M. (2018). A didactic experiment with cinema - Portuguese emigration and sense of belonging. Global Journal of Social Sciences Studies, 4(2), 70-77. https://doi.org/10.20448/807.4.2.70.77

Celuch, K. (2014). The Importance of Meetings and Incentive Travel in Times of Economic Growth for India and Poland. Global Management Journal, 6. https://web.a.ebscohost.com/abstract

Çevik, S., \& Sariipek, S. (2019). The Role of Unique Attractions in the Formation of City Image: The Case of Eskişehir Sazova Science Culture and Art Park1. CITY TOURISM, 33. https://www.researchgate.net/ publication/342479713_Determining_The_Contributions_of_Archeological_Sites_in_Turkey's_Cultural_ Tourism_Competitiveness

Chiu, L. K., \& Ananzeh, O. A. (2012). The role of MICE destination attributes on forming Jordan touristic image. Academic Research International, 3(1), 267.

Degarege, G. A., \& Lovelock, B. (2020). MICE tourism development in Ethiopia. Events Tourism, 196-214. https:// doi.org/10.4324/9780429344268-15

Dörfler, C. (2002). .MICE-SUCCESS FACTORS AND OPPORTUNITIES. Tourism and hospitality management, 8(1-2), 169-176. https://hrcak.srce.hr/index.php?show=clanak\&id_clanak_jezik=268125

Dwyer, L., \& Mistilis, N. (2016). Development of MICE tourism in Australia. Journal of Convention \& Exhibition Management, 1(4), 85-100. https://doi.org/10.1300/j143v01n04_07

Fang, W. (2020). Tourism in emerging economies. https://doi.org/10.1007/978-981-15-2463-9

Francisco, J. P. (2017). Assessment of the meetings, incentives, conventions, and exhibitions (MICE) industry in the Philippines. SSRN Electronic Journal. https://doi.org/10.2139/ssrn.2916012

Fredline, E. (2005). Host and guest relations and sports tourism. Sport in Society, 8(2), 263-279. https://doi. org/10.1080/17430430500087328

Ghaffara, J., Currie, G., \& Rahmitasari, N. (2018). Factors influencing MICE tourism development in pulau Seribu, Jakarta, Indonesia. TRJ Tourism Research Journal, 2(2), 45. https://doi.org/10.30647/trj.v2i2.35

Giao, H. N., \& Le Thai Son. (2020). MICE tourism development- Examination from the supply side in Dalat city, Vietnam. https://doi.org/10.31219/osf.io/r36yf 
Goeldner, C. R., Richie, B., \& McIntosh, R. (2001). Tourism: Principles, practices, philosophies (8th edition). International Journal of Tourism Research, 3(6), 516-517. https://doi.org/10.1002/jtr.294

Haguisan III, I. A., \& Mendoza, T. J. (2015). Bacolod City, Philippines as Meetings, Incentives, Conventions, and Events Destination. Development Education Journal of Multidisciplinary Research. https://lccbresearch.ph/ news/wp-content/uploads/2020/11/Bacolod-City-Philippines-as-Meetings-Incentives-Conventions-andEvents-Destination.pdf

Hamid, M., Ismail, N., Fuza, Z., Ahmad, K., \& Awang, K. (2012). Sustainable tourism development practices of MICE venue provider in East Coast region, peninsula Malaysia. Current Issues in Hospitality and Tourism, 8790. https://doi.org/10.1201/b12752-19

Han, H., Al-Ansi, A., Olya, H. G., \& Kim, W. (2019). Exploring halal-friendly destination attributes in South Korea: Perceptions and behaviors of Muslim travelers toward a non-Muslim destination. Tourism Management, 71, 151-164. https://doi.org/10.1016/j.tourman.2018.10.010

Hazarhun, E., Ceren, İ. Ş. Ç. İ., \& TEPECI, M. (2019). Determining The Contributions of Archeological Sites in Turkey's Cultural Tourism Competitiveness. CITY TOURISM, 108. https://www.researchgate.net/ publication/342479713_Determining_The_Contributions_of_Archeological_Sites_in_Turkey's_Cultural_ Tourism_Competitiveness

Hermelin, B. (2012). Global networks on the ground: the business hotel. Hotel spaces: urban and economic. https:// scholar.google.com/scholar

Jamgade, S. (2018). Scope of MICE Tourism as an Emerging Hospitality Industry.https://www.researchgate.net/ profile/Sweety-Jamgade/publication/329465968_Scope_of_MICE_Tourism_as_an_Emerging_Hospitality_ Industry/links/5cb89a3ca6fdcc1d499ee45a/Scope-of-MICE-Tourism-as-an-Emerging-Hospitality-Industry. pdf

Jones, C., \& Li, S. (2015). The economic importance of meetings and conferences: A satellite account approach. Annals of Tourism Research, 52, 117-133. https://doi.org/10.1016/j.annals.2015.03.004

Kapareliotis, I., Panopoulos, A., \& Panigyrakis, G. G. (2010). The influence of the Olympic Games on Beijing consumers' perceptions of their city tourism development. Asia Pacific Journal of Marketing and Logistics, 22(1), 90-100. https://doi.org/10.1108/13555851011013173

Katsitadze, Nana, \& Natsvlishvili, Ia. (2017). Development Opportunities of MICE Tourism in Developing Countries: Case of Georgia. International Journal of Business and Management Studies, 2158-1479. https://www. researchgate.net/profile/Ia-Natsvlishvili/publication/316600594_Development_Opportunities_of_MICE_ Tourism_in_Developing_Countries_Case_of_Georgia/links/5906d6114585152d2e96778b/DevelopmentOpportunities-of-MICE-Tourism-in-Developing-Countries-Case-of-Georgia.pdf

Kelly, I., \& Nankervis, T. (2001). Visitor destinations. John Wiley and Sons Australia, Ltd.https://www.cabdirect.org/ cabdirect/abstract/20013135631

Kerdpitak, C. (2019). The Influence of Destination Attributes on the MICE Tourism Industry in Bangkok, Thailand. International Journal of Innovation, Creativity, and Change, 10(1), 76-98.https://www.ijicc.net/images/ vol10iss1/10118_Kerdpitak_2019_E_R.pdf

Kim, E. G. (2019). Co-Created Destination Branding for Creative MICE Tourism: Building Synergies with Cultural Heritage Assets (Doctoral dissertation, Ph. D. Thesis, Arizona State University, Tempe, AZ, USA https://core. ac.uk/download/pdf/200250002.pdf

Kim, S. S., Sun, H., \& Ap, J. (2008). Is there competition in the exhibition market in Asia? Analysis of the positioning of major Asian exhibition host cities. Asia Pacific Journal of Tourism Research, 13(3), 205-227. https://doi. org/10.1080/10941660802280299

Kurtzman, J., \& Zauhar, J. (2003). A wave in time - The sports tourism phenomena. Journal of Sport \& Tourism, 8(1), 35-47. https://doi.org/10.1080/14775080306239

Law, C. M. (1993). Urban tourism: Attracting visitors to large cities. London: Mansell. https://www.cabdirect.org/ cabdirect/abstract/19941800797

Lewis, J. B., \& Delisle, L. (2004). Tourism as economic self-development in rural Nebraska: A case study. Tourism Analysis, 9(3), 153-166. https://doi.org/10.3727/1083542042781221

Macmillan Education Ltd, \& Meidan. (2015). Bank marketing management. Macmillan International Higher Education.

Marais, M., Du Plessis, E., \& Saayman, M. (2017). Critical success factors of a business tourism destination: Supplyside analysis. Acta Commercii, 17(1). https://doi.org/10.4102/ac.v17i1.423

Marques, J., \& Santos, N. (2016). Developing business tourism beyond major urban centers: The perspectives of local stakeholders. Tourism and hospitality management, 22(1), 1-15. https://doi.org/10.20867/thm.22.1.3

Martín, J. C., Román, C., \& Gonzaga, C. (2016). Quality of service and segmentation in the MICE industry: An approximation based on fuzzy logic. Journal of Convention \& Event Tourism, 18(1), 1-25. https://doi.org/10.1 080/15470148.2016.1154808

Mistilis, N., \& Dwyer, L. (2000). Information technology and service standards in MICE tourism. Journal of Convention \& Exhibition Management, 2(1), 55-65. https://doi.org/10.1300/j143v02n01_04

Mokras-Grabowska, J. (2016). Sports tourism: Terminological discussion. Turyzm, 26(1), 13-18. https://doi. org/10.1515/tour-2016-0001 
Monge, F., \& Brandimarte, P. (2011). MICE tourism in Piedmont: Economic perspective and quantitative analysis of customer satisfaction. Tourism: An International Multidisciplinary. Journal of Tourism, 6, 213- 220. http:// www.chios.aegean.gr/tourism/VOLUME_6_No1_art11.pdf

Morrison, A., \& Anderson, D. (2002). Destination branding. In Annual Meeting of the Missouri Association of Convention and Visitor Bureaus (p. 17).https://www.tandfonline.com/doi/abs/10.1080/1528008x.2012.645198

Oppermann, M. (1997). The future of tourism in the Pacific Rim. In M. Oppermann (Ed.), Pacific Rim tourism (pp. 240- 249). Wallingford: CABI https://www.cabdirect.org/cabdirect/abstract/19981800504

Ponte, J., Couto, G., Pimentel, P., \& Oliveira, A. (2018). Tourism activities and companies in a sustainable adventure tourism destination: The Azores. Tourism \& Management Studies, 14(4), 25-38. https://doi.org/10.18089/ tms.2018.14403

Ratajczak-Mrozek, M. (2014). Cooperation, Innovations, and Knowledge in MICE Tourist Product Perception.https:// www.researchgate.net/profile/Milena-Ratajczak-Mrozek/publication/266149437_Cooperation_innovations_ and_knowledge_in_MICE_tourist_product_perception/links/542908ac0cf238c6ea7ce68e/Cooperationinnovations-and-knowledge-in-MICE-tourist-product-perception.pdf

Rhaman, M. R. (2016). The socio-economic importance of tourism and its impact on the livelihood in South Asia: Case Rangamati, Bangladesh. https://www.theseus.fi/handle/10024/116404

Rogerson, C. M. (2015). The uneven geography of business tourism in South Africa. South African Geographical Journal, 97(2), 183-202. https://doi.org/10.1080/03736245.2015.1028984

Safaeva, S., \& Adilova, D. (2020). Mice tourism: Opportunities, priorities, problems, prospects. The American Journal of Applied Sciences, 02(11), 116-121. https://doi.org/10.37547/tajas/volume02issue11-21

Sangeetha, C. P. (2015). Customer perceptions and satisfaction towards mice tourism in Coimbatore. Semantic Scholar. https://www.semanticscholar.org/paper/Customer-Perceptions-And-Satisfaction-Towards-MiceSangeetha/a337e1398e69a5dcb3fffc6afa25f50e2d6ac52a?p2df

Shamshina, T., Labeev, V., \& Koryuhina, J. (2017). Theoretical and practical aspects of educational tourism. https:// bsa.edu.Iv/wp-content/docs/science/book/touristjournal1.pdf\#page=136

Singh, J., \& Parkash, R. (2016). MICE Tourism in India: Challenges and Opportunities! International Journal of Research and Engineering, 3(9). https://core.ac.uk/download/pdf/154060742.pdf

Smagina, N. (2017). The internationalization of the meetings-, incentives- conventions- and exhibitions(MICE) industry: Its influences on the actors in the tourism business activity. Journal of Economics and Management, 27, 96-113. https://doi.org/10.22367/jem.2017.27.06

Subash, T. (2015). Tourism in India: Potentials, Challenges, and Opportunities. IJRAR-International Journal of Research and Analytical Reviews, 2(4), 8-18. http://www.ijrar.com/upload_issue/ijrar_issue_222.pdf

Swarbrooke, J., \& Horner, S. (2012). Business travel and tourism. Routledge.https://www.taylorfrancis.com/books/ mono/10.4324/9780080490601/business-travel-tourism-john-swarbrooke-susan-horner

Sylla, M., Chruściński, J., Drużyńska, P., Płóciennik, P., \& Osak, W. (2015). Opportunities and limitations for MICE tourism development in Łódź. Turyzm, 25(2), 117-124. https://doi.org/10.1515/tour-2015-0011

Weber, K., \& Ladkin, A. (2003). The convention industry in Australia and the United Kingdom: Key issues and competitive forces. Journal of Travel Research, 42(2), 125-132. https://doi.org/10.1177/0047287503257489

World Tourism Organization TedQual certification system. (2014). Vol. 1: Executive introduction.

\section{Correspondence:}

CYBILL ANN A. RAMIREZ

ramirezcybillann@gmail.com

https://orcid.org/0000-0003-2061-1098 